\title{
Prenatal cadmium exposure is associated with shorter leukocyte telomere length in Chinese newborns
}

\author{
Lina Zhang ${ }^{1}$, Lulu Song ${ }^{1}$, Bingqing Liu', Mingyang Wu', Lulin Wang ${ }^{1}$, Bin Zhang ${ }^{2}$, Chao Xiong ${ }^{2}$, Wei Xia ${ }^{3}$, \\ Yuanyuan $\mathrm{Li}^{3}$, Zhongqiang $\mathrm{CaO}^{2}$, Youjie Wang ${ }^{1,3^{*}}$ and Shunqing $\mathrm{Xu}^{3^{*}}$
}

\begin{abstract}
Background: Newborn telomere length $(T L)$ is considered a potential marker for future disease and lifelong health, but few epidemiological studies have examined the determinants of $T L$ in early life. The study aim was to investigate whether there is an association between prenatal cadmium exposure and relative cord blood TL in Chinese newborns.

Methods: Participants were 410 mother-newborn pairs drawn from a prospective birth cohort study conducted in Wuhan, China, between November 2013 and March 2015. Urine samples were collected from pregnant women during their period of institutional delivery. Urinary cadmium concentrations were measured by inductively coupled plasma mass spectrometry. The real-time quantitative polymerase chain reaction detection was used to measure relative TL using genomic DNA isolated from umbilical cord blood leukocytes. Multivariate linear regression models were used to estimate the effect of prenatal urinary cadmium concentration on relative cord blood TL.

Results: The geometric mean of maternal urinary cadmium concentration was $0.68 \mu \mathrm{g} / \mathrm{g}$ creatinine. In the multivariateadjusted linear regression model, per doubling of maternal urinary cadmium concentration was associated with $6.83 \%$ (95\% Cl $-11.44 \%,-1.97 \% ; P=0.006)$ shorter relative cord blood TL. Stratified analyses indicated that the inverse association between prenatal urinary cadmium and newborn relative TL was more pronounced among female infants and mothers $<29$ years, while there were no significant effect modification according to infant sex $(P$ for interaction $=0.907)$ and maternal age $(P$ for interaction $=0.797)$.

Conclusions: The findings indicated that increased maternal urinary cadmium was associated with shortened relative cord blood TL. The results provide more evidence of the negative effects of environmental cadmium exposure and suggest that accelerated aging or cadmium-related diseases may begin in early life.
\end{abstract}

Keywords: Prenatal urinary cadmium, Telomere length, Cord blood, Newborns

\section{Background}

Cadmium is a heavy metal that is toxic at low levels. Cadmium is ubiquitously present in the environment mainly owing to human activities, such as mining, coal

\footnotetext{
* Correspondence: wangyoujie@mails.tjmu.edu.cn; xust@hust.edu.cn ${ }^{1}$ Department of Maternal and Child Health, School of Public Health, Tongji Medical College, Huazhong University of Science and Technology, Hangkong Road 13, Wuhan 430030, Hubei, China

${ }^{3}$ Key Laboratory of Environment and Health, Ministry of Education and Ministry of Environmental Protection, and State Key Laboratory of Environmental Health (Incubation), School of Public Health, Tongji Medical College, Huazhong University of Science and Technology, Hangkong Road 13, Wuhan 430030, Hubei, China

Full list of author information is available at the end of the article
}

burning, industrial emissions, household wastes, and the using and disposing of cadmium-containing products [1]. Consumption of food containing cadmium and cigarette smoking are two major causes of cadmium exposure [2]. In addition, contaminated dust and air can contribute to cadmium exposure [3]. Once absorbed, cadmium efficiently accumulates in the human body, mainly in the kidneys, where it is retained with a biological half-time around 10-30 years [2]. Urinary cadmium concentration mainly influenced by the body burden of cadmium is proportional to the concentration in the kidney $[2,3]$. Women, particularly pregnant

(c) The Author(s). 2019 Open Access This article is distributed under the terms of the Creative Commons Attribution 4.0 International License (http://creativecommons.org/licenses/by/4.0/), which permits unrestricted use, distribution, and reproduction in any medium, provided you give appropriate credit to the original author(s) and the source, provide a link to the Creative Commons license, and indicate if changes were made. The Creative Commons Public Domain Dedication waiver (http://creativecommons.org/publicdomain/zero/1.0/) applies to the data made available in this article, unless otherwise stated. 
women, accumulate more cadmium than men [4, 5]. Epidemiological studies have reported that prenatal cadmium exposure increased the risk of adverse perinatal outcomes, such as preterm birth [6,7] and lower birth weight [8-10].

Telomeres are nucleoprotein structures located at the end of chromosomes; their function is to maintain chromosome integrity and genome stability [11]. Telomere shortening occurs during each DNA replication cycle in somatic cells, as DNA polymerase cannot completely replicate the end telomeric DNA during cellular division [12]. Shortened telomere length (TL) is associated with aging-related diseases, such as type 2 diabetes mellitus [13, 14], cardiovascular disease [15, 16], and cancer [17, 18].

$\mathrm{TL}$ variation in later life is determined by the initial or newborn setting of $\mathrm{TL}$ and the subsequent attrition rate [19]. TL at birth is an important predictor for TL in adulthood [20]. A small but growing body of epidemiological studies have explored the relationship between newborn TL and prenatal environmental exposure, such as perfluoroalkyl and polyfluoroalkyl [21], intrauterine tobacco exposure [22], polycyclic aromatic hydrocarbons [23], residential traffic exposure [24], and residential fine particulate matter (PM 2.5) [25]. One cross-sectional study, conducted by Lin et al, found that cadmium concentration in placental tissue was negatively related to placental TL among Chinese participants living in metal polluted areas [26]. No study to date has evaluated whether prenatal cadmium exposure is associated with the alteration of newborn leukocyte TL in the general population. As cadmium can cross the placental barrier, maternal cadmium is strongly associated with cadmium concentrations in newborn umbilical cord blood [27, 28]. We hypothesized that prenatal cadmium exposure might affect newborn TL. Here, we intended to evaluate the association between maternal urinary cadmium concentration, a marker of long-time cumulative exposure, and relative cord blood TL in a Chinese population and to provide evidence that shorter TL is a possible mechanism of cadmium-induced toxicity.

\section{Methods}

\section{Study population}

The study was conducted from November 2013 to March 2015 at the Wuhan Children's Hospital (Wuhan Maternal and Child Healthcare Hospital), a tertiary medical institution in Wuhan city, China. A total of 418 mothers met the following enrollment criteria: (1) lived in Wuhan city, Hubei province (in central China), (2) with a singleton gestation, (3) had received prenatal care and intended to deliver at the study hospital, and (4) agreed to provide a urine sample and fill out a questionnaire. Eight newborns had poor quality cord blood DNA; therefore, 410 mothernewborn pairs were included in the final analysis. The study protocol was approved by the ethics committee of Tongji Medical College, Huazhong University of Science and Technology, and the Wuhan Children's Hospital (Wuhan Maternal and Child Healthcare Hospital). Individual written informed consent was obtained from all mothers at enrollment.

\section{Urine sample collection and cadmium measurement}

Maternal spot urine samples were collected in the study hospital during the period of mothers waiting for labor (within 3 days before delivery), and all urine samples were stored at $-20^{\circ} \mathrm{C}$ in polypropylene tubes before measurement.

Urinary metal levels were measured using inductively coupled plasma mass spectrometry (ICP-MS) (Agilent 7700; Agilent Technologies). In brief, frozen urine samples were thawed at room temperature $\left(20^{\circ} \mathrm{C}-25^{\circ} \mathrm{C}\right)$, then each urine sample was mixed thoroughly using a vortex mixer, and 1.2\% $(v / v)$ HNO3 was introduced for overnight nitrification, and then the sample was digested at $40{ }^{\circ} \mathrm{C}$ for $1 \mathrm{~h}$. Cadmium concentration measurement was conducted for each sample using ICP-MS. A control urine sample of standard reference material (SRM2670a Toxic Elements in Urine; National Institute of Standards and Technology, Gaithersburg, MD, USA) was used for external quality control in each batch. The low and high certified concentrations $(\mu \mathrm{g} / \mathrm{L})$ of cadmium were $0.059 \pm$ 0.0034 and $5.16 \pm 0.11$, respectively. All concentration measurements were within the certified range (5\%). Interday and intraday variations of cadmium were tested using cadmium concentrations measured from the standard reference material human urine sample. The interday and intraday coefficients of variation $(\mathrm{CVs})$ were $0.36 \%$ and $0.89 \%$, respectively. The limit of detection for cadmium was $0.001 \mu \mathrm{g} / \mathrm{L}$. There were no undetected samples in the present study.

Urinary creatinine was measured using a creatinine kit (Mindray BS-200 CREA Kit; Shenzhen Mindray Bio-medical Electronics Co., Ltd). Creatinine-corrected urinary cadmium concentrations $(\mu \mathrm{g} / \mathrm{g}$ creatinine) were used in the final statistical analysis and to account for the effect of variation in spot urine diluteness.

\section{Cord blood collection and relative leukocyte TL examination} Umbilical cord blood samples from newborns were collected immediately postpartum. Plasma and blood cells were separated and stored at $-80^{\circ} \mathrm{C}$ for later analysis.

Genomic DNA in each cord blood sample was isolated using a Wizard ${ }^{\circ}$ Genomic DNA Purification Kit (Promega Corporation, Madison, WI, USA). DNA samples with an A260/A280 ratio within the range 1.8 to 2.0 were considered eligible. Relative TL in each DNA sample was examined using the real-time quantitative polymerase chain reaction (qPCR) method. Relative TL was determined using the ratio of telomere repeat copy 
number to single-copy gene copy number ( $\mathrm{T} / \mathrm{S}$ ratio). Two primer pairs were used for the amplification of telomeric gene and single-copy gene (human $\beta$-globulin (HBG)), respectively. The primer sequences of telomeric gene and single-copy gene (HBG) were as follows: Forward primer (Tel-Forward): 5'-ACACTAAGGTTTGG GTTTGGGTTTGGGTTTGGGTTAGTGT-3'; reverse primer (Tel-Reverse): 5'-TGTTAGGTATCCCTATCCC TATCCCTATCCCTATCCCTAACA-3'; forward primer (HBG-1): 5'-GTGCACCTGACTCCTGAGGAGA-3'; reverse primer (HGB-2): $5^{\prime}$-CCTTGATACCAACCTGCCC AG-3'. For telomeric gene, the reaction mixture contained 10 ng genomic DNA, $1 \times$ KAPA SYBR ${ }^{\circ}$ FAST qPCR kit Master MIX (KAPA Biosystems), $270 \mathrm{nM}$ of the forward, and $900 \mathrm{nM}$ of the reverse; RNase-free water was added to a final volume of $10 \mu \mathrm{L}$. For single-copy gene (HBG), the reaction mixture contained $10 \mathrm{ng}$ genomic DNA, $1 \times$ SYBR FAST qPCR kit Master MIX (KAPA Biosystems), $200 \mathrm{nM}$ of the forward, and $200 \mathrm{nM}$ of the reverse; RNase-free water was added to a final volume of $10 \mu \mathrm{L}$. Each sample was assayed in triplicate in a 384-well plate using the ViiA $^{\text {ti }} 7$ Dx Real-Time PCR System (Applied Biosystems). The standard deviation (SD) of the Ct values of three replicates for each sample below 0.30 was considered a repeatable result; otherwise the measurement was conducted again in a new 384-well plate. The PCR cycling conditions were $50^{\circ} \mathrm{C}$ for $2 \mathrm{~min}$ and $95^{\circ} \mathrm{C}$ for 3 min to activate DNA polymerase, then 40 cycles of denaturation at $95^{\circ} \mathrm{C}$ for $3 \mathrm{~s}$ and annealed/extended at $60{ }^{\circ} \mathrm{C}$ for $30 \mathrm{~s}$. Melting curve analysis was included at the end of each run to validate the specificity of the PCR products. Standard curve, plotted using a standard reference genomic DNA sample, is a 5-point curve produced using 1:4 serial dilutions of DNA concentration from 104 to $0.4 \mathrm{ng} / \mu \mathrm{L}$ $\left(R^{2} \geq 0.99\right)$. The standard reference genomic DNA sample was derived from a mixture of genomic DNA of 50 samples randomly selected from our study population. On each run, a 5-point serial dilution of standard reference genomic DNA sample was run to assess qPCR amplification efficiency. The qPCR amplification efficiency in the present study was $108 \%$ for telomeres and $103 \%$ for single-copy gene. To examine the interrun reproducibility, we set three replicates for standard reference genomic DNA sample in each 384-well plate, and the CV for interrun was calculated using $\mathrm{Ct}$ values of single-copy gene of standard reference sample in all qPCR assays. The interrun and intrarun CVs of single-copy gene were $4.1 \%$ and $3.0 \%$, respectively. The CVs within triplicates of the telomere runs and single-copy gene runs were $0.53 \%$ and $0.74 \%$, respectively.

\section{Assessment of covariates}

Information on maternal age at delivery (in years), education, and active/passive smoking during pregnancy was obtained via standard questionnaires administered by trained nurses at the study hospital during the period of institutional delivery. Information on infant sex, gestational age (in weeks) at birth, parity, gestational diabetes mellitus, and hypertensive disorders in pregnancy were obtained from medical records. Passive smoking refers to second-hand smoking exposure during pregnancy. The self-reported date of last menstrual period was used to estimate gestational age. Maternal prepregnancy weight was self-reported and height was measured using a stadiometer at the first prenatal care visit in the study hospital, generally during the first trimester of pregnancy. Prepregnancy body mass index (BMI) $\left(\mathrm{kg} / \mathrm{m}^{2}\right)$ was expressed as the ratio of weight in kilograms $(\mathrm{kg})$ and the square of height in meters $\left(\mathrm{m}^{2}\right)$. Hypertensive disorders in pregnancy in this study included chronic hypertension, pre-eclampsia, and gestational hypertension.

\section{Statistical analysis}

All database managements and statistical analyses were performed using SAS 9.4 software (SAS Institute Inc., Cary, NC, USA). The Shapiro-Wilk test was used to test the distribution of continuous data. Population characteristics were described as mean \pm SD for normally distributed data, median (interquartile range, IQR) for skewed data, and numbers (percentages) for categorical data. Relative cord blood TL and metal concentrations were natural log (Ln)-transformed to approximate a normal distribution.

We used a multivariate linear regression model to estimate the regression coefficient $(\beta)$ and standard error (SE) of the association between urinary cadmium concentration (Ln-transformed) and relative cord blood TL (Ln-transformed). The percentage change in relative TL for per doubling of urinary cadmium concentration was estimated as $\left(e^{(\ln 2 \times \beta)}-1\right) \times 100 \%$, and the $95 \%$ confidence inter$\operatorname{val}(95 \% \mathrm{CI})$ was estimated as $\left(e^{[\ln 2 \times(\beta \pm 1.96 \times \mathrm{SE}]}-1\right) \times 100 \%$. To ensure the robustness of the results, sensitivity analyses were performed omitting subjects with gestational diabetes mellitus and hypertensive disorders in pregnancy. To evaluate potential modification effects, further analyses were sub-grouped by infant sex (male or female) and maternal age at delivery $(<29$ or $\geq 29$ years, the median value). The Wald test was used to test the interaction across subgroups.

Covariates allowed in the regression model were selected based on published literatures [22, 29-32] or if they individually caused $>10 \%$ of the changes in the effect estimates [33]. The covariates in the adjusted models were infant sex (male or female), gestational age (continuous, weeks), maternal age at delivery (continuous, years), education (junior school or below, high school, college or above), prepregnancy BMI (continuous, $\mathrm{kg} / \mathrm{m}^{2}$ ), prenatal passive smoking (yes or no), parity (primiparous or multiparous), hypertensive disorders in 
pregnancy (yes or no), gestational diabetes mellitus (yes or no), urinary zinc (Ln-transformed, $\mu \mathrm{g} / \mathrm{g}$ creatinine), and urinary selenium (Ln-transformed, $\mu \mathrm{g} / \mathrm{g}$ creatinine). We did not adjust for maternal smoking because all mothers in this study were non-smokers. There were no missing data for the covariates added in the adjusted models.

\section{Results}

The characteristics of the mother-newborn pairs are shown in Table 1. Of the newborns, 206 (50.2\%) were males and 204 (49.8\%) were females. The mean \pm SD gestational age was $(39.4 \pm 1.2)$ weeks. The participating mothers were 22 to 44 years old, with an average age of $29.2 \pm 3.4$ years. Of the 410 mothers, $313(76.4 \%)$ had an educational level of college or above, 133 (32.4\%) were exposed to environmental tobacco smoke during pregnancy, and 339 (82.7\%) were primiparas.

Table 2 shows the maternal urinary cadmium concentrations. The geometric means of the uncorrected and creatinine-corrected urinary cadmium concentrations

Table 1 Characteristics of the 410 mother-newborn pairs in present study

\begin{tabular}{|c|c|}
\hline Variables & $\begin{array}{l}\text { Mean } \pm \text { SD/ } \\
\text { Median (IQR)/ } \\
\text { Number (\%) }\end{array}$ \\
\hline \multicolumn{2}{|l|}{ Infant sex } \\
\hline Male & $206(50.2)$ \\
\hline Female & $204(49.8)$ \\
\hline Gestational age (weeks) & $39.4 \pm 1.2$ \\
\hline Maternal age at delivery(years) & $29.2 \pm 3.4$ \\
\hline \multicolumn{2}{|l|}{ Education } \\
\hline Junior school or below & $28(6.8)$ \\
\hline High school & $69(16.8)$ \\
\hline College or above & $313(76.4)$ \\
\hline \multicolumn{2}{|c|}{ Passive smoking during pregnancy } \\
\hline Yes & $133(32.4)$ \\
\hline No & $277(67.6)$ \\
\hline Prepregnancy BMI $\left(\mathrm{kg} / \mathrm{m}^{2}\right)$ & $21.2 \pm 3.0$ \\
\hline \multicolumn{2}{|l|}{ Parity } \\
\hline Primiparous & $339(82.7)$ \\
\hline Multiparous & $71(17.3)$ \\
\hline \multicolumn{2}{|c|}{ Hypertensive disorders in pregnancy } \\
\hline Yes & $12(2.9)$ \\
\hline No & $398(97.1)$ \\
\hline \multicolumn{2}{|l|}{ Gestational diabetes mellitus } \\
\hline Yes & $41(10.0)$ \\
\hline No & $369(90.0)$ \\
\hline Relative cord blood TL & $0.74(0.56-0.92)$ \\
\hline
\end{tabular}

Data presented as mean \pm SD for normally distributed data, or median (IQR) for skewed distributed data, or numbers (percentage) for categorical data were $0.33 \mu \mathrm{g} / \mathrm{L}$ (5th-95th percentile, $0.09-1.16 \mu \mathrm{g} / \mathrm{L}$ ) and $0.68 \mu \mathrm{g} / \mathrm{g}$ creatinine (5th-95th percentile, $0.30-1.84 \mu \mathrm{g} / \mathrm{g}$ creatinine), respectively.

Table 3 shows that prenatal urinary cadmium was significantly and inversely associated with relative cord blood TL in the unadjusted and adjusted models. In the unadjusted model, per doubling of urinary cadmium contributed to $5.30 \%$ (95\% CI $-9.63 \%,-0.77 \%$; $P=0.022)$ shorter relative cord blood TL. After adjustment for newborn characteristics (infant sex and gestational age), a doubling of urinary cadmium was associated with $5.34 \%$ (95\% CI $-9.66 \%,-0.81 \% ; P=0.022$ ) shorter relative cord blood TL. After further adjustment for maternal characteristics (maternal age at delivery, education, passive smoking during pregnancy, prepregnancy BMI, parity, hypertensive disorders in pregnancy and gestational diabetes mellitus), prenatal urinary cadmium remained significantly and inversely associated with relative TL; a doubling of urinary cadmium was associated with $5.73 \%$ (95\% CI $-10.18 \%,-1.06 \% ; P=0.017$ ) shorter relative cord blood TL. After further adjustment for urinary zinc and urinary selenium, per doubling of maternal urinary cadmium contributed to $6.83 \%$ (95\% CI: $-11.44 \%$, $-1.97 \%$; $P=0.006)$ shorter relative cord blood TL.

In sensitivity analyses (Table 4), the results were essentially unchanged after excluding data for 12 mothers with hypertensive disorders in pregnancy and 41 mothers with gestational diabetes mellitus.

Table 5 shows the results of the subgroup analyses. In the fully adjusted model, percentage changes in relative cord blood TL of per doubling of maternal urinary cadmium were $-5.52 \%(95 \% \mathrm{CI}-12.24 \%, 1.71 \%)$ in males, $-8.26 \%$ (95\% CI $-14.45 \%,-1.63 \%$ ) in females, $-8.47 \%$ (95\% CI $-15.45 \%,-0.91 \%)$ in mothers < 29 years, and $5.29 \%$ (95\% CI $-11.28 \%, 1.11 \%$ ) in mothers $\geq 29$ years. No significant interactions were found between prenatal urinary cadmium and infant sex $(P$ for interaction $=0.907)$ or maternal age $(P$ for interaction $=0.797)$ regarding the alteration of relative cord blood TL.

\section{Discussion}

The present results indicate that prenatal cadmium exposure was inversely associated with relative cord blood TL after adjustment for potential confounders; per doubling of prenatal urinary cadmium contribute to $6.83 \%$ shorter relative cord blood TL.

Maternal urinary cadmium measured during delivery was a useful indicator of maternal environmental cumulative cadmium exposure throughout pregnancy or over a longer period. In the present study, cadmium was detected in all maternal urine samples, indicating that participating mothers were widely exposed to cadmium in their daily lives. Maternal urinary cadmium concentrations in the present study (geometric mean $0.33 \mu \mathrm{g} / \mathrm{L}$ or 
Table 2 Distribution of maternal urinary cadmium concentrations

\begin{tabular}{lccccccc}
\hline & Geometric & Mean \pm SD & \multicolumn{3}{l}{ Percentiles } & & \\
\cline { 4 - 7 } & mean & & 5 th & 25th & 50th & 75th & 95th \\
\hline Uncorrected cadmium $(\mu \mathrm{g} / \mathrm{L})$ & 0.33 & $0.44 \pm 0.35$ & 0.09 & 0.19 & 0.35 & 0.59 & 1.16 \\
Creatinine-corrected cadmium $(\mu \mathrm{g} / \mathrm{g}$ creatinine) & 0.68 & $0.82 \pm 0.70$ & 0.30 & 0.47 & 0.66 & 0.96 & 1.84 \\
\hline
\end{tabular}

$0.68 \mu \mathrm{g} / \mathrm{g}$ creatinine; median $0.35 \mu \mathrm{g} / \mathrm{L}$ or $0.66 \mu \mathrm{g} / \mathrm{g}$ creatinine) were higher than those reported in the USA (geometric mean $0.31 \mu \mathrm{g} / \mathrm{g}$ creatinine) [9] and on average comparable to those found in Europe (median $0.31 \mu \mathrm{g} / \mathrm{L}$ ) [34] and Japan (geometric mean $0.77 \mu \mathrm{g} / \mathrm{g}$ creatinine) [35], but lower than those reported in Bangladesh (median $0.63 \mu \mathrm{g} / \mathrm{L}$ ) [10].

Our detection of shorter relative TL associated with increased cadmium exposure is consistent with findings from three previous studies. One study [26] revealed that cadmium concentration in placental tissue was negatively correlated with placental TL among Chinese participants in areas known to be polluted by metals. However, placental tissue is usually contaminated by maternal tissue or blood and so may not be suitable for measuring newborn TL. The other two studies conducted on adults [36] and adolescents [37] demonstrated that higher levels of cadmium exposure were associated with shorter leukocyte TL. Only one previous study [38] conducted on 8-year-old children in Poland near a site of industrial pollution, reported a null association between cadmium exposure and telomere shortening, possibly because of the relatively small sample size $(n=99)$.

There are some potential biological mechanisms underlying the association between prenatal cadmium exposure and shortened relative cord blood TL. Both experimental [39] and epidemiological studies [40-42] have reported a positive association between environmental cadmium exposure and oxidative stress. Telomeres are sensitive to oxidative damage because of their high guanine content [43]. Reactive oxygen species, particularly hydroxyl radicals, can result in single-strand

Table 3 Percentage change in relative TL by prenatal cadmium exposure $(N=410)$

\begin{tabular}{lll}
\hline & Percentage change $(\%)^{*}(95 \% \mathrm{Cl})$ & $P$ value \\
\hline Unadjusted & $-5.30(-9.63,-0.77)$ & 0.022 \\
Model A & $-5.34(-9.66,-0.81)$ & 0.022 \\
Model B & $-5.73(-10.18,-1.06)$ & 0.017 \\
Model C & $-6.83(-11.44,-1.97)$ & 0.006 \\
\hline
\end{tabular}

*Estimates are percentage changes in relative cord blood TL of per doubling of urinary cadmium concentration

Model A, adjustment for newborn characteristics (infant sex and gestational age) Model B, additionally adjustment for maternal characteristics (maternal age at delivery, educational level, passive smoking in pregnancy, prepregnancy BMI, parity, hypertensive disorders in pregnancy, and gestational diabetes mellitus) Model C, additionally adjustment for zinc (Ln-transformed, $\mu \mathrm{g} / \mathrm{g}$ creatinine) and selenium (Ln-transformed, $\mu \mathrm{g} / \mathrm{g}$ creatinine) breaks, and telomeric DNA may be deficient in repairing single-strand breaks compared with genomic DNA [44]. Thus, oxidative stress may be a mechanism by which cadmium exposure leads to telomere shortening. Furthermore, chronic cadmium exposure can stimulate the cumulative load of inflammatory cytokines [42, 45, 46], including TNF-a, IL-6, C-reactive protein, and fibrinogen. Elevated levels of inflammation can contribute to telomere shortening by accelerating cell turnover and cell replicative senescence, as well as by induction of oxidative stress and regulating telomerase activity [47]. In addition, cadmium is a potent carcinogen and can disturb human DNA repair systems, particularly the excision and mismatch repair systems [48]. Whether these processes affect telomere maintenance in fetuses requires further research.

The sex-specific effect of maternal cadmium exposure on neonatal adverse outcomes has been documented, with increased susceptibility of females [10, 49, 50]. In the stratified analysis, we found that the inverse association between maternal cadmium exposure and relative cord blood TL was more pronounced in female infants. The underlying mechanisms are unclear. One possible explanation is that the sex difference in cadmium-induced changes in epigenetic regulation of genes governing telomere dynamics. Studies have reported that cadmium exposure in early life caused different DNA methylation pattern in girls and boys [51]. Kipple et al. found that methylated sites for genes involved in cell death were sex different [52]. Cell death-related genes were important regulators for telomere attrition rate [53]. Another possible explanation is the action of insulin-like growth factor 1 (IGF-1). Epidemiological studies demonstrated that lower level of IGF-1 was associated with shorter TL [54, 55]. Cadmium exposure was found to be associated with lower

Table 4 Sensitivity analyses

\begin{tabular}{llll}
\hline & $n$ & Percentage change $(\%)^{*}(95 \% \mathrm{Cl})$ & $P$ value \\
\hline Overall & 410 & $-6.83(-11.44,-1.97)$ & 0.006 \\
$\begin{array}{l}\text { Excluding hypertension } \\
\text { disorders in pregnancy }\end{array}$ & 398 & $-6.92(-11.60,-1.98)$ & 0.006 \\
$\begin{array}{l}\text { Excluding gestational } \\
\text { diabetes mellitus }\end{array}$ & 369 & $-6.54(-11.52,-1.28)$ & 0.015 \\
\hline
\end{tabular}

Models' adjustments are according to model $\mathrm{C}$ in Table 3. *Estimates are percentage changes of relative cord blood TL of per doubling of urinary cadmium concentration 
Table 5 Associations between prenatal cadmium exposure and relative cord blood TL, stratified by infant sex and maternal age

\begin{tabular}{llll}
\hline Subgroup & $n$ & $\begin{array}{l}\text { Percentage change }(\%)^{*} \\
(95 \% \mathrm{Cl})\end{array}$ & $P$ for interaction \\
\hline Infant sex & & & 0.907 \\
Male & 206 & $-5.52(-12.24,1.71)$ & \\
Female & 204 & $-8.26(-14.45,-1.63)$ & \\
Maternal age & & & 0.797 \\
at delivery (years) & & & \\
$<29$ & 201 & $-8.47(-15.45,-0.91)$ & \\
$\geq 29$ & 209 & $-5.29(-11.28,1.11)$ & \\
\hline
\end{tabular}

Models' adjustments are according to model $\mathrm{C}$ in Table 3. *Estimates are percentage changes in relative cord blood TL of per doubling in urinary cadmium concentration

concentration of IGF-1 [56]. We speculated that female newborns, who was reported to have higher level of IGF-1 in cord blood/plasma than males [57, 58] might suffer more cadmium-induced telomere shortening. The stratified analysis also indicated that the inverse association between prenatal cadmium exposure and newborn relative TL was more evident among mothers < 29 years. Telomere attrition was an important indicator of aging [59]. A reasonable explanation might be that the risk factors for biological aging might mask the effect of maternal cadmium exposure on newborn TL among high-risk mothers ( $\geq 29$ years) and leave adverse effect to be manifested among relatively healthy mothers $(<29$ years).

$\mathrm{TL}$ in adults is associated with age-related diseases and mortality [13-18]. The initial or newborn setting of $\mathrm{TL}$ is a major determinant of TL in later life $[19,20]$. Our findings provide additional evidence that diseases in later life may have their roots in early life. Furthermore, cadmium exposure is associated with signs of aging, such as mitochondrial dysfunction [60], genomic instability [61], and cell senescence [62]. Considering that telomere attrition is an important biomarker of aging [59], our results add to the accumulating evidence on the adverse effects of cadmium exposure on aging.

The potential limitations of this study should be noted. First, we did not measure cord blood cadmium concentrations, which might provide direct measure of fetal cadmium exposure. Researches showed that maternal cadmium level is highly associated with cadmium concentrations in newborn cord blood [27, 28]. Second, spot urinary cadmium concentration might not precisely reflect cadmium exposure throughout pregnancy. However, previous studies have shown that urinary cadmium levels are rather constant over the pregnancy period [63] and are stable at multiple points across a day [64]. As the half-time of cadmium in the human body is very long, urinary cadmium concentration is considered a better surrogate for cumulative exposure $[2,65,66]$. Third, although our results were consistent after multiple adjustments, additional unmeasured or unknown confounding factors, such as cord blood cell type, newborn telomerase activity, and maternal cotinine level may have biased our findings. Finally, our sample was drawn from a Chinese population, so caution is needed before generalizing the results to other populations.

\section{Conclusions}

In summary, prenatal exposure to cadmium was associated with decreased newborn cord blood TL. The results provide more evidence of the negative effects of environmental cadmium exposure and suggest that accelerated aging or cadmium-related diseases may begin in early life.

\begin{abstract}
Abbreviations
BMI: Body mass index; Cl: Confidence interval; HBG: Human $\beta$-globulin; ICPMS: Inductively coupled plasma mass spectrometry; IGF: Insulin-like growth factor; IQR: Interquartile range; Ln: Natural log; qPCR: Real-time quantitative polymerase chain reaction; SD: Standard deviation; TL: Telomere length
\end{abstract}

\section{Acknowledgements}

We gratefully thank all the study participants in this study and the staffs of the Wuhan Children's Hospital (Wuhan Maternal and Child Healthcare Hospital).

\section{Funding}

This study was supported by the National Key R\&D Program of China (2017YFC0212003), National Natural Science Foundation of China (91643207, 81273083), and the Hubei Province Health \& Family Planning Scientific Research Project (WJ2017Z001).

Availability of data and materials

The datasets for the current study are available from the corresponding author on reasonable request.

\section{Authors' contributions}

YJW, SQX, LLS, BQL, and WMY conceived and designed the study; LNZ, LLS, LLW, BZ, CX, and ZQC performed the DNA extraction; LNZ, BQL, and WMY measured cord blood telomere; $W X$ and $Y Y L$ performed the cadmium examination; YJW, SQX, LLS, and BQL performed quality control of the database; LNZ and LLS performed data interpretation and statistical analyses. LNZ wrote the manuscript; YJW critically revised the manuscript for important intellectual content. All authors critically reviewed and approved the manuscript.

\section{Ethics approval and consent to participate}

The study protocol was approved by the ethics committee of the Tongji Medical College, Huazhong University of Science and Technology (No. S152), and the Wuhan Children's Hospital (Wuhan Maternal and Child Healthcare Hospital) (No. 2016003). Individual written informed consent was obtained from all participating mothers at enrollment.

Consent for publication

Not applicable.

\section{Competing interests}

The authors declare that they have no competing interests.

\section{Publisher's Note}

Springer Nature remains neutral with regard to jurisdictional claims in published maps and institutional affiliations.

\section{Author details}

${ }^{1}$ Department of Maternal and Child Health, School of Public Health, Tongji Medical College, Huazhong University of Science and Technology, Hangkong Road 13, Wuhan 430030, Hubei, China. 'Wuhan Children's Hospital (Wuhan Maternal and Child Healthcare Hospital), Tongji Medical College, Huazhong University of Science and Technology, Wuhan, Hubei, China. ${ }^{3}$ Key Laboratory of Environment and Health, Ministry of Education and Ministry of 
Environmental Protection, and State Key Laboratory of Environmental Health (Incubation), School of Public Health, Tongji Medical College, Huazhong University of Science and Technology, Hangkong Road 13, Wuhan 430030, Hubei, China.

\section{Received: 14 August 2018 Accepted: 16 January 2019} Published online: 06 February 2019

\section{References}

1. Faroon O, Ashizawa A, Wright S, Tucker P, Jenkins K, Ingerman L, Rudisill C. Toxicological Profile for Cadmium. Atlanta: Agency for Toxic Substances and Disease Registry (US); 2012. https://www.ncbi.nlm.nih.gov/books/ NBK158838/. Accessed 1 Aug 2018

2. Järup $L$, Akesson $A$. Current status of cadmium as an environmental health problem. Toxicol Appl Pharmacol. 2009;238(3):201-8.

3. Nawrot TS, Staessen JA, Roels HA, Munters E, Cuypers A, Richart T, Ruttens A, Smeets K, Clijsters H, Vangronsveld J. Cadmium exposure in the population: from health risks to strategies of prevention. Biometals. 2010;23(5):769-82.

4. Berglund $M$, Lindberg $A L$, Rahman M, Yunus M, Grandér M, Lönnerdal B, Vahter M. Gender and age differences in mixed metal exposure and urinary excretion. Environ Res. 2011;111(8):1271-9.

5. Nishijo M, Satarug S, Honda R, Tsuritani I, Aoshima K. The gender differences in health effects of environmental cadmium exposure and potential mechanisms. Mol Cell Biochem. 2004;255(1-2):87-92.

6. Yang J, Huo W, Zhang B, Zheng T, Li Y, Pan X, Liu W, Chang H, Jiang M, Zhou $A$, et al. Maternal urinary cadmium concentrations in relation to preterm birth in the healthy baby cohort study in China. Environ Int. 2016;94:300-6.

7. Wang H, Liu L, Hu YF, Hao JH, Chen YH, Su PY, Yu Z, Fu L, Tao FB, Xu DX. Association of maternal serum cadmium level during pregnancy with risk of preterm birth in a Chinese population. Environ Pollut. 2016;216:851-7.

8. Cheng L, Zhang B, Zheng T, Hu J, Zhou A, Bassig BA, Xia W, Savitz DA, Buka S, Xiong C, et al. Critical windows of prenatal exposure to cadmium and size at birth. Int J Environ Res Public Health. 2017;14(1):58

9. Romano ME, Enquobahrie DA, Simpson C, Checkoway H, Williams MA. Maternal body burden of cadmium and offspring size at birth. Environ Res. 2016;147:461-8.

10. Kippler M, Tofail F, Gardner R, Rahman A, Hamadani JD, Bottai M, Vahter M. Maternal cadmium exposure during pregnancy and size at birth: a prospective cohort study. Environ Health Perspect. 2012;120(2):284-9.

11. Blackburn EH. Switching and signaling at the telomere. Cell. 2001;106(6):661-73.

12. Blackburn EH. Telomeres and telomerase: their mechanisms of action and the effects of altering their functions. FEBS Lett. 2005;579(4):859-62.

13. Zee RY, Castonguay AJ, Barton NS, Germer S, Martin M. Mean leukocyte telomere length shortening and type 2 diabetes mellitus: a case-control study. Transl Res. 2010;155(4):166-9.

14. Willeit P, Raschenberger J, Heydon EE, Tsimikas S, Haun M, Mayr A, Weger S, Witztum JL, Butterworth AS, Willeit J, et al. Leucocyte telomere length and risk of type 2 diabetes mellitus: new prospective cohort study and literature-based meta-analysis. PLoS One. 2014;9(11):e112483.

15. Fitzpatrick AL, Kronmal RA, Gardner JP, Psaty BM, Jenny NS, Tracy RP, Walston J, Kimura M, Aviv A. Leukocyte telomere length and cardiovascular disease in the cardiovascular health study. Am J Epidemiol. 2007:165(1):14-21.

16. Brouilette SW, Moore JS, MCMahon AD, Thompson JR, Ford I, Shepherd J, Packard CJ, Samani NJ. Telomere length, risk of coronary heart disease, and statin treatment in the west of Scotland primary prevention study: a nested case-control study. Lancet. 2007;369(9556):107-14.

17. Wentzensen IM, Mirabello L, Pfeiffer RM, Savage SA. The association of telomere length and cancer: a meta-analysis. Cancer Epidemiol Biomark Prev. 2011;20(6):1238-50.

18. Willeit P, Willeit J, Mayr A, Weger S, Oberhollenzer F, Brandstatter A, Kronenberg F, Kiechl S. Telomere length and risk of incident cancer and cancer mortality. JAMA. 2010;304(1):69-75.

19. Hjelmborg JB, Dalgård C, Möller S, Steenstrup T, Kimura M, Christensen K, Kyvik KO, Aviv A. The heritability of leucocyte telomere length dynamics. J Med Genet. 2015;52(5):297-302.

20. Heidinger BJ, Blount JD, Boner W, Griffiths K, Metcalfe NB, Monaghan P. Telomere length in early life predicts lifespan. Proc Natl Acad Sci. 2012; 109(5):1743-8.

21. Liu H, Chen Q, Lei L, Zhou W, Huang L, Zhang J, Chen D. Prenatal exposure to perfluoroalkyl and polyfluoroalkyl substances affects leukocyte telomere length in female newborns. Environ Pollut. 2018;235:446-52.
22. Salihu HM, Pradhan A, King L, Paothong A, Nwoga C, Marty PJ, Whiteman V. Impact of intrauterine tobacco exposure on fetal telomere length. Am J Obstet Gynecol. 2015;212(2):205 e201-8.

23. Perera F, Lin CJ, Qu L, Tang D. Shorter telomere length in cord blood associated with prenatal air pollution exposure: benefits of intervention. Environ Int. 2018;113:335-40.

24. Bijnens E, Zeegers MP, Gielen M, Kicinski M, Hageman GJ, Pachen D, Derom C, Vlietinck R, Nawrot TS. Lower placental telomere length may be attributed to maternal residential traffic exposure; a twin study. Environ Int. 2015;79:1-7.

25. Martens DS, Cox B, Janssen BG, Clemente DBP, Gasparrini A, Vanpoucke C, Lefebvre W, Roels HA, Plusquin M, Nawrot TS. Prenatal air pollution and newborns' predisposition to accelerated biological aging. JAMA Pediatr. 2017;171(12):1160-7.

26. Lin S, Huo X, Zhang Q, Fan X, Du L, Xu X, Qiu S, Zhang Y, Wang Y, Gu J. Short placental telomere was associated with cadmium pollution in an electronic waste recycling town in China. PLoS One. 2013:8(4):e60815.

27. Kippler M, Hoque AM, Raqib R, Ohrvik H, Ekstrom EC, Vahter M. Accumulation of cadmium in human placenta interacts with the transport of micronutrients to the fetus. Toxicol Lett. 2010;192(2):162-8.

28. Sakamoto M, Yasutake A, Domingo JL, Chan HM, Kubota M, Murata K Relationships between trace element concentrations in chorionic tissue of placenta and umbilical cord tissue: potential use as indicators for prenatal exposure. Environ Int. 2013;60:106-11.

29. Wojcicki JM, Olveda R, Heyman MB, Elwan D, Lin J, Blackburn E, Epel E. Cord blood telomere length in Latino infants: relation with maternal education and infant sex. J Perinatol. 2016;36(3):235-41.

30. Martens DS, Nawrot TS. Air pollution stress and the aging phenotype: the telomere connection. Curr Environ Health Rep. 2016;3(3):258-69.

31. Factor-Litvak P, Susser E, Kezios K, McKeague I, Kark JD, Hoffman M, Kimura M, Wapner R, Aviv A. Leukocyte telomere length in newborns: implications for the role of telomeres in human disease. Pediatrics. 2016;137(4):e20153927.

32. Martens DS, Plusquin M, Gyselaers W, De Vivo I, Nawrot TS. Maternal prepregnancy body mass index and newborn telomere length. BMC Med. 2016;14(1):148.

33. Greenland S. Modeling and variable selection in epidemiologic analysis. Am J Public Health. 1989;79(3):340-9.

34. Akesson $A$, Berglund $M$, Schutz $A$, Bjellerup $P$, Bremme $K$, Vahter $M$. Cadmium exposure in pregnancy and lactation in relation to iron status. Am J Public Health. 2002;92(2):284-7.

35. Shirai S, Suzuki Y, Yoshinaga J, Mizumoto Y. Maternal exposure to low-level heavy metals during pregnancy and birth size. J Environ Sci Health A Tox Hazard Subst Environ Eng. 2010;45(11):1468-74.

36. Zota AR, Needham BL, Blackburn EH, Lin J, Park SK, Rehkopf DH, Epel ES. Associations of cadmium and lead exposure with leukocyte telomere length: findings from National Health and Nutrition Examination Survey, 1999-2002. Am J Epidemiol. 2015;181(2):127-36.

37. Fillman T, Shimizu-Furusawa H, Ng CFS, Parajuli RP, Watanabe C. Association of cadmium and arsenic exposure with salivary telomere length in adolescents in Terai. Nepal Environ Res. 2016;149:8-14.

38. Pawlas N, Plachetka A, Kozlowska A, Broberg K, Kasperczyk S. Telomere length in children environmentally exposed to low-to-moderate levels of lead. Toxicol Appl Pharmacol. 2015;287(2):111-8.

39. Nair AR, Degheselle O, Smeets K, Van Kerkhove E, Cuypers A. Cadmiuminduced pathologies: where is the oxidative balance lost (or not)? Int J Mol Sci. 2013;14(3):6116-43.

40. Tellez-Plaza M, Jones MR, Dominguez-Lucas A, Guallar E, Navas-Acien A. Cadmium exposure and clinical cardiovascular disease: a systematic review. Curr Atheroscler Rep. 2013;15(10):356.

41. Lee DH, Lim JS, Song K, Boo Y, Jacobs DR Jr. Graded associations of blood lead and urinary cadmium concentrations with oxidative-stress-related markers in the U.S. population: results from the third national health and nutrition examination survey. Environ Health Perspect. 2006;114(3):350-4.

42. Colacino JA, Arthur AE, Ferguson KK, Rozek LS. Dietary antioxidant and antiinflammatory intake modifies the effect of cadmium exposure on markers of systemic inflammation and oxidative stress. Environ Res. 2014;131:6-12.

43. von Zglinicki T. Oxidative stress shortens telomeres. Trends Biochem Sci. 2002;27(7):339-44.

44. Houben JM, Moonen HJ, van Schooten FJ, Hageman GJ. Telomere length assessment: biomarker of chronic oxidative stress? Free Radic Biol Med. 2008;44(3):235-46 
45. Lin YS, Rathod D, Ho WC, Caffrey JJ. Cadmium exposure is associated with elevated blood C-reactive protein and fibrinogen in the U.S. population: the third national health and nutrition examination survey (NHANES III, 19881994). Ann Epidemiol. 2009;19(8):592-6.

46. Dong W, Simeonova PP, Gallucci R, Matheson J, Flood L, Wang S, Hubbs A, Luster Ml. Toxic metals stimulate inflammatory cytokines in hepatocytes through oxidative stress mechanisms. Toxicol Appl Pharmacol. 1998;151(2):359-66.

47. O'Donovan A, Pantell MS, Puterman E, Dhabhar FS, Blackburn EH, Yaffe K, Cawthon RM, Opresko PL, Hsueh WC, Satterfield S, et al. Cumulative inflammatory load is associated with short leukocyte telomere length in the health, aging and body composition study. PLoS One. 2011;6(5):e19687.

48. Giaginis C, Gatzidou E, Theocharis S. DNA repair systems as targets of cadmium toxicity. Toxicol Appl Pharmacol. 2006;213(3):282-90.

49. Taylor CM, Golding J, Emond AM. Moderate prenatal cadmium exposure and adverse birth outcomes: a role for sex-specific differences? Paediatr Perinat Epidemiol. 2016;30(6):603-11.

50. Chatzi L, lerodiakonou D, Margetaki K, Vafeiadi M, Chalkiadaki G, Roumeliotaki T, Fthenou E, Pentheroudaki E, McConnell R, Kogevinas M, et al. Prenatal exposure to cadmium and child growth, obesity and cardiometabolic traits. Am J Epidemiol. 2019;188(1):141-50.

51. Dharmadasa P, Kim N, Thunders M. Maternal cadmium exposure and impact on foetal gene expression through methylation changes. Food Chem Toxicol. 2017;109(Pt 1):714-20.

52. Kippler M, Engstrom K, Mlakar SJ, Bottai M, Ahmed S, Hossain MB, Raqib R, Vahter M, Broberg K. Sex-specific effects of early life cadmium exposure on DNA methylation and implications for birth weight. Epigenetics. 2013;8(5):494-503.

53. Entringer S, de Punder K, Buss C, Wadhwa PD. The fetal programming of telomere biology hypothesis: an update. Philos Trans R Soc Lond B Biol Sci. 2018;373(1741):20170151.

54. Barbieri M, Paolisso G, Kimura M, Gardner JP, Boccardi V, Papa M, Hjelmborg JV, Christensen K, Brimacombe M, Nawrot TS, et al. Higher circulating levels of IGF-1 are associated with longer leukocyte telomere length in healthy subjects. Mech Ageing Dev. 2009;130(11-12):771-6.

55. Kaplan RC, Fitzpatrick AL, Pollak MN, Gardner JP, Jenny NS, McGinn AP, Kuller LH, Strickler HD, Kimura M, Psaty BM, et al. Insulin-like growth factors and leukocyte telomere length: the cardiovascular health study. J Gerontol A Biol Sci Med Sci. 2009;64(11):1103-6.

56. Turgut S, Kaptanoglu B, Turgut G, Emmungil G, Genc O. Effects of cadmium and zinc on plasma levels of growth hormone, insulin-like growth factor I, and insulin-like growth factor-binding protein 3. Biol Trace Elem Res. 2005; 108(1-3):197-204.

57. Vatten LJ, Nilsen ST, Odegard RA, Romundstad PR, Austgulen R. Insulin-like growth factor I and leptin in umbilical cord plasma and infant birth size at term. Pediatrics. 2002;109(6):1131-5.

58. Geary MP, Pringle PJ, Rodeck CH, Kingdom JC, Hindmarsh PC. Sexual dimorphism in the growth hormone and insulin-like growth factor axis at birth. J Clin Endocrinol Metab. 2003;88(8):3708-14.

59. Lopez-Otin C, Blasco MA, Partridge L, Serrano M, Kroemer G. The hallmarks of aging. Cell. 2013;153(6):1194-217.

60. Vriens A, Nawrot TS, Baeyens W, Den Hond E, Bruckers L, Covaci A, Croes K, De Craemer S, Govarts E, Lambrechts N, et al. Neonatal exposure to environmental pollutants and placental mitochondrial DNA content: a multi-pollutant approach. Environ Int. 2017;106:60-8.

61. Filipic M. Mechanisms of cadmium induced genomic instability. Mutat Res. 2012;733(1-2):69-77.

62. Wang T, Yuan Y, Zou H, Yang J, Zhao S, Ma Y, Wang Y, Bian J, Liu X, Gu J, et al. The ER stress regulator Bip mediates cadmium-induced autophagy and neuronal senescence. Sci Rep. 2016;6:38091.

63. Hernandez M, Schuhmacher M, Fernandez JD, Domingo JL, Llobet JM. Urinary cadmium levels during pregnancy and postpartum. A longitudinal study. Biol Trace Elem Res. 1996;53(1-3):205-12.

64. Wang YX, Feng W, Zeng Q, Sun Y, Wang P, You L, Yang P, Huang Z, Yu SL, Lu WQ. Variability of metal levels in spot, first morning, and 24-hour urine samples over a 3-month period in healthy adult Chinese men. Environ Health Perspect. 2016;124(4):468-76.

65. Borjesson J, Bellander T, Jarup L, Elinder CG, Mattsson S. In vivo analysis of cadmium in battery workers versus measurements of blood, urine, and workplace air. Occup Environ Med. 1997;54(6):424-31.

66. Whanger PD. Cadmium effects in rats on tissue iron, selenium, and blood pressure; blood and hair cadmium in some Oregon residents. Environ Health Perspect. 1979;28:115-21.

\section{Ready to submit your research? Choose BMC and benefit from}

- fast, convenient online submission

- thorough peer review by experienced researchers in your field

- rapid publication on acceptance

- support for research data, including large and complex data types

- gold Open Access which fosters wider collaboration and increased citations

- maximum visibility for your research: over $100 \mathrm{M}$ website views per year

At BMC, research is always in progress.

Learn more biomedcentral.com/submissions 